\begin{tabular}{|l|l|l|}
\hline \multicolumn{2}{|c|}{ PublisherInfo } \\
\hline \hline PublisherName & $:$ & BioMed Central \\
\hline \hline PublisherLocation & $:$ & London \\
\hline \hline PublisherImprintName & $:$ & BioMed Central \\
\hline \hline
\end{tabular}

\title{
Organochlorine pesticides: an effect on estrogen activity?
}

\begin{tabular}{|c|c|c|}
\hline \multicolumn{3}{|c|}{ ArticleInfo } \\
\hline ArticleID & : & 3654 \\
\hline ArticleDOI & : & 10.1186/bcr-1999-66632 \\
\hline ArticleCitationID & : & 66632 \\
\hline ArticleSequenceNumber & : & 20 \\
\hline ArticleCategory & : & Paper Report \\
\hline ArticleFirstPage & : & 1 \\
\hline ArticleLastPage & : & 3 \\
\hline ArticleHistory & : & $\begin{array}{lll}\text { RegistrationDate } & : 1999-10-14 \\
\text { OnlineDate } & : 1999-10-14\end{array}$ \\
\hline ArticleCopyright & : & Current Science Ltd1999 \\
\hline ArticleGrants & : & \\
\hline ArticleContext & : & 1305822 \\
\hline
\end{tabular}




\section{Keywords}

chlordane, estrogen receptor, estrogen-related receptor, persistent organic pollutant, toxaphene

\section{Introduction}

Estrogen-related receptor (ERR) $\alpha-1$ shares a high sequence homology with estrogen receptors $\alpha$ and $\beta$. ERR $\alpha-1$ is a member of the orphan nuclear receptor family since neither estrogen nor any other ligand has been reported to bind the receptor. However, ERR $\alpha-1$ may modify the effect of estrogens on gene promoters by both competition for DNA binding and via ER-ERR $\alpha-1$ protein interaction.

\section{Aims}

To identify ligands for ERR $\alpha-1$ and to investigate their effect on modulating gene activation by estrogens.

\section{Comments}

The identification of known persistent organic pollutants as antagonists for the previously orphan receptor ERR $\alpha-1$ and demonstration that they may interfere with aromatase gene expression and activity are important findings. However, these investigations were performed using ERR $\alpha-1$ overexpression and micromolar concentrations of the compounds. The relevance of such findings to environmental levels of the compounds merits further investigation.

\section{Methods}

Ligands were identified using a yeast one-hybrid hERR $\alpha-1-S 1$ reporter strain. Their effects on aromatase gene promoter activity were tested in the ER-negative breast cancer cell line SK-BR-3, into which hERR $\alpha-1$ and a reporter construct were transfected. Effects of hERR $\alpha-1$ transfection (with and 
without ligand) on endogenous aromatase activity were measured in both SK-BR-3 breast cancer cells and HepG2 hepatoma cells.

\section{Results}

Two organochlorine pesticides, toxaphene and chlordane, were found to increase ERR $\alpha$-1-mediated expression of the reporter enzyme $\beta$-galactosidase in a yeast-based assay. In transfection experiments using the SK-BR-3 breast cancer cell line, micromolar concentrations of both the compounds were found to have an antagonist activity against ERR $\alpha$-1-mediated expression of the reporter chloramphenicol acetyltransferase (CAT). Toxaphene was demonstrated to interfere with ERR $\alpha-1-$ GRIP1 coactivator interaction and was also shown to antagonise the increase in aromatase activity observed when hERR $\alpha-1$ was transfected into either SK-BR-3 breast cancer cells or HepG2 hepatoma cells.

\section{Discussion}

This is the first time that ligands have been identified for the orphan receptor ERR $\alpha-1$, and the study suggests that both toxaphene and chlordane may act as receptor antagonists. Toxaphene and chlordane

are among the 12 persistent organic pollutants identified by the United Nations Environment Programme as requiring urgent attention. Their antagonistic effects on ERR $\alpha-1$ and modulation of aromatase expression/estrogen biosynthesis could have a critical effect on normal endocrine function and may play a role in the pathogenesis of breast cancer.

\section{References}

1. Yang C, Chen S: Two organochlorine pesticides, toxaphene and chlordane, are antagonists for estrogen-related receptor $\alpha-1$ orphan receptor. Cancer Res. 1999, 59: 4519-4524. 